\title{
Institutional Transformation of Ukraine's Agricultural Sector
}

\author{
Tetiana Zinchuk, Nataliia Kutsmus, Oleksandr Kovalchuk, Vitalii \\ Dankevych, Tetiana Usiuk ${ }^{1}$
}

\begin{abstract}
The complex analysis of the main stages of Ukraine's agricultural sector development for the independence period has been done in the paper. It was established, that institutional changes in the agricultural sector of economy occurred concerning following institutions: private property, state regulation, pricing, social capital, competition. The peculiarities of land and property private ownership forming as agri-reforms basis have been determined. Post-Soviet institutions destruction caused rapid decrease of economic development and rural population welfare at the first stage of transformations. The main tendencies of agrarian sector functioning under market conditions, providing growth of the agricultural production and export potential of Ukraine have been identified. It was proved, that progressive economic changes did not provide similar results in rural areas development. As a result, the necessity of focusing on humancentric model of rural development was grounded.
\end{abstract}

Key words: agriculture, agricultural enterprise, institutions, private household, land, rural development, export potential.

JEL Classification: F 140, Q180

Received: 6 March 2016 / Accepted: 9 February 2017/Sent for Publication: 21 March 2017

\section{Introduction}

Ukraine has been developing as a country with an open economy for more than two decades. The transition from centrally planned to market economy was accompanied by quantitative and qualitative changes in all spheres of national economy. The transformation processes in the agricultural sector were influenced by the creation of new institutions, the formation of institutional structure of agricultural market and adaptation of the participants to market conditions.

Theory and practice of agrarian reform historically reflect the idea of institutional paradigm (Williamson, 2001; North, 1993), the essence of which is to change the "rules of

\footnotetext{
${ }^{1}$ Zhytomyr National Agroecological University (ZNAU), 7, Staryi boulevard, Zhytomyr, 10008, Ukraine; zintshuk@gmail.com, kutsmusn@ukr.net, o.d.kovalchuk@gmail.com,+380675906551, corresponding author, dankevych-v@ @rambler.ru, usjuktanja@gmail.com.
} 
the game" in the behavior of economic agents. The role of institutions in the agricultural sector in market conditions is provided through the understanding of classical institutional directions of economic development. Methodological foundations of the structural transformation was laid by the representatives of institutional approach: T. Veblen social and psychological concept (Veblen, 1984), J. Commons - social and legal concept (Commons, 1931), W. Mitchell - opportunistic direction (Mitchell, 1930), J. Galbraith - social direction (Galbraith, 1976), R. Coase - transaction cost theory and the theory of property rights (Coase, 1937) etc. Multi-vector nature of economic research is proved by their scientific contribution.

Institutional transformation in the agricultural sector is a very complex continuous process of restructuring the existing institutional system. It requires considerable financial and intellectual resources and ongoing costs (Catygrobova, 2013; Mamchur, 2010). In particular, this is the change in the formal and informal rules on legislative and regulatory level. First of all, these changes in Ukraine concerned the institute of property, government regulation, price formation, competition, development of social capital, etc. The purpose of these changes was to create a favorable institutional environment, which is an important motivating factor for generating new ideas and innovation technologies in the development of agribusiness. Under the new institutional conditions, agriculture reoriented itself to transformation into a highly competitive branch of economy. In terms of national interests the expected result of reforms was supposed to be a food security of the state (Lopatinsky, 2006; Malik and Shpykulyak 2010) and the full realization of the economic potential of the agricultural sector.

Despite the positive expectations transformation processes had their own specific characteristics and negative consequences under the conditions of destruction of the Soviet institutional system. Firstly, a significant increase in transaction costs was noted, which led to decline in the economy and welfare of the population. Secondly, due to the chaotic and inconsistent implementation of market-oriented legislative institutions a large number of institutional traps (taxes and fees avoidance, shadow economy, corruption) formed. Thirdly, institutional matrix as a set of effective changes in the social and economic, political, and legal systems did not provide the expected economic growth both at the first and the following stages of agrarian reforms. Finally, fundamental changes in the institutions of ownership (liquidation of collective ownership) and the emergence of new forms of economic activity did not contribute to motivation for labour in agriculture. They didn't become the driver of a favorable informal institutional environment for the countryside with its usual system of values. Thus, entering the path of market reforms, the agricultural sector turned out to be institutionally unsecure and inertia inactive.

During the period of independence and complicated process of market-oriented institutional reforms, the desired effect was not achieved in the agricultural sector. Economic development priorities were prevailing over the social ones. This situation aggravated the problem of forming the policy of sustainable rural development considering the lessons of previous reforms. Accordingly, the aim of this study became the following: analysis and evaluation of social and economic consequences of agrarian reforms in Ukraine's economy. 
This aim defines the following research tasks:

- $\quad$ to analyze the reasons of slow adaptation of the agricultural sector to market institutions in the sphere of land use and land tenure;

- $\quad$ to identify the causes of imbalance in the sectors of agriculture (crop and livestock) in market conditions;

- $\quad$ to assess institutional steps to expand export opportunities of the agricultural sector;

- $\quad$ to analyze the nature of institutional contradictions between the spheres of agricultural production and rural development;

- to identify the role and importance of informal institutions (traditions, customs, mentality, informal contacts, norms of behavior, etc.) in rural development policy;

- $\quad$ to analyze the main indicators of transformational changes in the agricultural sector of economy;

- $\quad$ to assess and to define priorities of the institutional development of the agricultural sector.

Research methodology based on a number of general philosophical methods. Historical method was used to study genesis and stages of agrarian reforms in Ukraine's economy, which resulted in the transition from administrative to market conditions of development. Method of scientific abstraction was applied to justify the agricultural sector features under conditions of abstraction from post-Soviet approaches to functioning of agriculture. Method of induction and deduction was used to disclose the nature of social and economic development crisis of the Ukraine's agricultural sector under influence of current economic globalization trends. Analysis and synthesis method gave the possibility to study the structure and to evaluate agricultural sector export potential, to determine the dynamics of foreign trade of agro-food products.

Conceptual framework of research was formed in accordance with the existing theories, in particular: the resource concept of economy potential (Calyuzhna, 2014), within which understanding of the essence of agricultural sector resource potential and dominant role of land resources was formed; the classical concept of comparative and modern concept of competitive advantages (Porter, 2008) in international trade, basing on which the evaluation of agricultural sector export capacity was made; the concept of rural development (Borodina, 2010), which oriented the research on the rural economy multifunctionality and human-centered principles of development; the concept of welfare (Aronsson, Löfgren, 2007), which was implemented through a set of freedoms and opportunities of rural population to get sustainable livelihoods and to meet the life needs.

\section{Stages and peculiarities of institutional transformation in the agricultural sector}

The beginning of the transformation processes in the agricultural sector of Ukraine as an independent state is characterized by the transition from the administrative command system to market methods of management. Accordingly, it was necessary to reform the Soviet methods of farming. The shift from the orientation towards the sustainable increase of the production volume to the social market economy occurred gradually under the influence of legislative changes and new principles of agrarian institutional system. Evaluating the peculiarities of the transformation changes in the economic development of the agricultural sector we have distinguished three stages of reforms aimed at the 
institutional transformation in order to bring agriculture to international level. The implementation of agrarian reforms at each stage had some consequences for: a) development of land relations; b) system of agricultural production; c) foreign trade and creating export potential of the agricultural sector; d) social development of rural areas.

\subsection{The first stage 1990-1999}

The first stage which span from 1990 to 1999 can be characterized as creation of preconditions for denationalization and privatization of land and property belonging to collective and state agricultural enterprises, and their immediate reorganization (Borodina, 2012). At this stage, the institutional platform was formed, which laid the "rules" of the game regarding formal and informal institutions.

\section{a) Evolution of land relations}

The first stage of the agricultural sector transformation was land denationalization and free transfer of the ownership to collective farms and citizens of Ukraine (Resolution of the Verkhovna Rada of Ukraine "On acceleration of the land reform and land privatization", 1992; the Decree of the Cabinet of Ministers of Ukraine "On land privatization", 1992; the Decree of the President of Ukraine "On procedure how to share land that was transferred into collective ownership to agricultural enterprises and organizations", 1995). The land was transferred on condition that it would be shared and divided with the status of private property. The main task for the transformation of land relations was to improve effectiveness of land resources by changing their owner (Sabluk, 2001). The main principle of reforming land relations in the agriculture became the transfer of the land ownership to those who cultivate it.

The transfer of land to collective ownership of agricultural enterprises became the intermediate stage of land reform in Ukraine. It ensured a gradual, conflict-free transition from the state to private ownership of land intended for agricultural use. It was realized by means of dividing land into shares and issuing certificates to employees of enterprises, which guaranteed their right to have a share in the collective ownership of land (Dobriak, 2015). Certificate holders gained the right to leave enterprises with their land shares freely.

Institutional consequences of the first stage of land reform were:

1. development of regulatory and methodological support for the land reform;

2. project of denationalization and privatization for donating land to collective and private property.

The result of the transformation of land relations was the creation of 7.3 thousand agricultural enterprises, 600 joint stock companies and more than 100 cooperatives and issuing certificates to 2 million farmers (Fedorov, 2011).

At the same time, institutional changes at the initial stage of land reform did not have the expected result. The expected renewal of agricultural production, activization of the investment processes, improvement of the welfare of rural population were not achieved (Mogylnyi, 2005). The reasons for that were the following:

- unfavorable economic situation in the country; 
- lack of financial support of reforms;

- $\quad$ lack of experience in independent management among farmers;

- unwillingness of society to accept market changes.

The transformation of land relations was mainly procedural, due to the simple re-issue of documents. The real change in property relations and organizational structure of farm management did not occur. Collective ownership of land at that time functioned actually as direct ownership of agricultural enterprises. As a result, the majority of their employees practically remained alienated from the land and from the results of economic and enterprise management (Diyesperov, 2010). The sharing in this period mainly showed signs of formal privatization, which slowed down the process of formation of private land ownership. Due to parcelling of agricultural land, private land ownership became a serious obstacle for the agrarian reform instead of being its driving force. Under such conditions, there was deterioration in the quality characteristics of land and also general stagnation in the development of land relations.

\section{b) The efficiency of agricultural production}

Transformational changes in land relations and market reforms in the economy were reflected in agricultural production. The implementation of agrarian reforms did not lead to the creation of an effective private landowner. There was a significant decline in production level of farm gross output (by 1.9 times), in particular, livestock - by 2.3 times, agriculture $-1,4$ times.

Reduction in crop production was the result of decreasing equipment capability, reducing the amount of applied organic and mineral fertilizers and the use of plant protection products. Disparity in prices, credit and tax policy were formed not in favor of agriculture.

During this period, industry began to experience disparities in agricultural production in favour of crops. For instance, in 1990 the share of crop production was $51.5 \%$ in the total production, and in $1999-55.9 \%$. The main reason was a constant unprofitability of animal farming. Producers deliberately got rid of unprofitable production by means of reducing the number of animals. It was the beginning of destruction and partial conversion of cattle farms, and cultivated pastures turned into shrubs. Reducing the volume of livestock production led to increased shortages of food of animal origin. Livestock industry in Ukraine began to decline and the state lost the opportunity not only to export animal products abroad, but also to meet the domestic needs of the population.

A definite tendency developed in crop production, it was directed towards reducing yields of major crops: cereals (from $35.1 \mathrm{dt} / \mathrm{ha}$ in 1990 to 20.1 in 1999) and sugar beets (from $276 \mathrm{~kg} / \mathrm{ha}$ in 1990 to $180.3 \mathrm{~kg} / \mathrm{ha}$ in 1999 ).

Negative tendencies in the livestock and crop production led to decreasing efficiency of agriculture. The level of unprofitability of agricultural production in 1999 was $1.8 \%$ in comparison with $42.6 \%$ profitability in 1990 as presented in table 1 . 
Table 1: Indices of Gross Agricultural Production, \% (1990 year = $100 \%)$

\begin{tabular}{c|c|c|c|c|c}
\hline & 1995 & 2000 & 2005 & 2010 & 2015 \\
\hline Gross agricultural production & 65,0 & 53,4 & 63,5 & 68,9 & 88,2 \\
Gross crop production & 73,1 & 63,8 & 78,7 & 85,6 & 121 \\
Gross animal production & 56,5 & 42,4 & 47,4 & 51,2 & 53,7 \\
\hline
\end{tabular}

Source: UkrStat

\section{c) Changes in foreign trade and formation of export potential}

In the process of economic changes in agricultural production and land relations reorientation of foreign trade to western markets took place. The main tasks in the system of foreign economic activity were: a fundamental change of emphasis in foreign policy, stabilization of export potential, redevelopment of export structure. The research results showed that from the first half of the ninetieth to 1997 products focused mainly on Russia dominated in the structure of export; these were sugar, alcohol, grains, meat, and flour, fat and sunflower oil. A very significant share of transactions in bilateral foreign trade relations was performed on a barter basis. A high level of integration in the postSoviet space was observed.

At the same time, export of agri-food products to markets in Western countries significantly reduced in the ninetieth while the conditions for import were relatively favorable. At the beginning of market transformation import regime was characterized as liberal. In 1991-1994 the majority of customs tariffs were at 5-8\% and the maximum rate did not exceed 30\%. (Haidutskyi et al., 2005) Increasing import was the result of the loss of food sovereignty of Ukraine, decline in agricultural production, reduction of per capita consumption of basic foodstuffs. Due to liberalization of access of goods to the domestic market there was a glut of domestic food market with imported goods (Padalka, 2008; Sabluk et al., 2005).

Gradually export was liberalized, especially in 1996 due to the massive export of animals, certain types of food and finished food products of plant origin. The share of export of agricultural and food products in total export was $20.7 \%$ (tab. 1). During all years, except 1999, the balance of export and import was positive. However, the share of agricultural products, sales of which were controlled by the state, remained quite significant (33\% grain, $64 \%$ milk, $78 \%$ beef, $50 \%$ pork and chicken meat) (World Bank, 2004).

Considerate changes in the processes of sales of agricultural products took part in the second half of the 90s. The main achievements were the abolition of the planned sales arrangements and adopting the Decree of the Cabinet of Ministers of Ukraine on amendments to the Law of Ukraine "On Joint Customs Tariff" (1993). It created preconditions for improving pricing and cooperation with foreign partners, the overall equation of external and internal prices for export products, limited use of indicative prices. For the first time the concept of import regulation was suggested. Due to this the period from 1995 to 1999 was characterized by the significant growth of foreign trade turnover. 
In 1994 Ukraine began the process of joining the GATT/WTO and bringing legislation in line with the agreements of the organization. The idea was to liberalize international trade and remove trade restrictions. However, in the period from 1996 to 1997 agricultural export was limited by quotas and licenses. The government set the indicative and minimum export prices for the majority of goods (Lerman et al., 2007). In 1996 the highest level of import was recorded - 8.2\% (compared to 3-6\% in developed countries) (tab. 1). One of the reasons for this situation was bringing food goods across the border without customs control, which significantly worsened the conditions for bringing Ukrainian products to foreign markets. In order to reduce import deliveries the state legislation on tariff improvement and technical protection of the Ukrainian market was adopted, namely the Decree of the President of Ukraine "On peculiarities of application of tariff restrictions on import of agricultural commodities according to the rules and principles of GATT/WTO" (1997) and the Law of Ukraine" On state regulation of agricultural import "(1997). As a result, there was a downward trend in import of agricultural and food industries (Haidutskyi et al., 2005).

In general, the processes of reforming at this stage were very slow, incomplete and inconsistent, which was highlighted by the majority of scientists and researchers (Ostashko, 2004). A clear programme of reforms at the national level was absent. A significant lag from the Central and Eastern Europe was observed in the area of institutional reforms and the processes of formation of market infrastructure.

\section{d) The social consequences of transformations}

The adoption of the Law of Ukraine "On the priority of social development of rural areas and agriculture in the national economy" in 1990 did not ensure progress in rural development. Changes in the rural economy as part of the reform of the agricultural sector led to the formation of new conditions of life of the rural population. These economic changes led to a crisis of rural society through:

- violation of established sources of employment and income formation;

- destruction of paternalistic Soviet system of social protection;

- $\quad$ inability of farmers to adapt quickly to market principles of life.

First of all, this crisis was expressed in the aggravation of problems of human development: impoverishment of population, growth of unemployment, degradation of labor potential, growth of depopulation (Shepotko et al. 2000). The last factor became the main one in determining the dynamics of the demographic decline of the rural areas. The death rate increased by $14 \%$ with the simultaneous fall of birth rate - by more than $21 \%$ (Zubec at al. 1999). During the 90s there was an active aging process of population in rural areas.

The rate of reduction in the number of children and adolescents became threatening, which was explained by the inability of rural people to provide material wealth and favorable living conditions. Owing to these depopulation processes correlation between the age groups of retired people and children among the rural population reached a rate of 2.1. Negative demographic tendencies among the rural population led to excessive load of working population: for every thousand people of working age there were 1,019 incapacitated people (Yakuba, 1999). 
Despite this, the age structure of rural population in Ukraine underwent significant positive changes in the middle of this stage. Worsening of the situation on the city labor market, which traditionally attracted rural youth, led to the stabilization of their cohort in rural areas (Usenko, 2012). The economic crisis actually "broke" the established trend of annual reducing in number of rural population to 200-250 thousand people owing to migration to the cities. In 1992-1993 due to growing cost of living, worsening of employment problems and closing programs of providing housing a positive migration balance was observed. It almost made up the natural decrease in the number of rural people. However, the potential for reverse migration dried up in 1994 and since 1998 its balance was of negative value again.

Negative social trends in rural development during 1990-1999, experienced substantial strengthening due to the forced break in the mentality of rural people (Shepotko et al. 2000). Their ongoing alienation from the means of production and labor outcomes resulted in the inability of rural people to adapt quickly to new institutional conditions, increased nihilistic moods, total passivity in the social and economic processes.

Regardless of the desire and participation of rural population, social and economic transformation of the $90 \mathrm{~s}$ became irreversible. A traditional source of employment agricultural enterprise - retained its value only for every second employee. The leading economic and creating role in rural families was given to private farm households. Private farm households began to give about $50 \%$ of the total resources of the rural population and created opportunities for informal employment of $60 \%$ of those released from agricultural enterprises.

\subsection{The second stage (2000-2004)}

The second that spanned into a period 2000-2004 was characterized by the completion of restructuring agricultural enterprises by means of introduction of land and property private ownership. Conditions of institutional environment outlined the limits of activities for industrial and business enterprises, encouraged the formation of the legal and regulatory environment, legal traditions and culture. Issues of land ownership were the basis of political and social conflicts of the period. They led to asymmetric development of business patterns with priorities for huge goods production.

\section{a) Evolution of land relations}

The adoption of regulations regarding the formation of a land market had significant influence on the development of land relations (Land Code of Ukraine 2001, the Law of Ukraine "On Land Management" 2003, "On the Protection of Land" 2003, "On state control over the use and protection of land" 2003," On the evaluation of land" 2003). The objectives of the period of agrarian reform were mostly achieved. Collective enterprises were liquidated, new legal forms of enterprises were created on their funds and private land shares of rural population, namely limited liability companies, farms, agricultural cooperatives and private households.

At this stage, the dual structure of agriculture was formed: the corporate sector (agricultural enterprises) and individual sector (private households and farms). 34715 new agricultural organizations were created, they owned and used 18,833.5 thousand hec- 
tares of land (Burdeynyuk, 2010). Redistribution of land among different forms of agricultural enterprises took place. Land area of agricultural enterprises of corporate sector decreased, while the sizes of private farms and farms of the population increased.

\section{b) The efficiency of agricultural production}

This period was characterized by the establishment of new economic relations based on the principles of market economy. That is, there was a movement from the system of total state intervention to market.

Despite a slight increase in agricultural production, yields and livestock productivity remained low. Economic results of activities of agricultural enterprises decreased, the share of unprofitable agricultural enterprises increased from $33.8 \%$ in 2000 to $53.8 \%$ in 2004. The cost of main assets of agriculture tended to decrease. In 2000 the value of main assets of agriculture was $11.7 \%$ of their total value in the economy, and in 2004 $7.4 \%$. The level of wearing out of main assets of agricultural enterprises in 2004 exceeded $50 \%$. Production and technical base of agricultural enterprises needed updating. The agricultural sector engaged less than $5.0 \%$ of all investments in the economy.

Progressive point of this period was the adoption of the Law of Ukraine "On stimulation of agriculture development for the period 2001-2004." (2001). As a result of the law the share of state budget to support agriculture increased from $2.1 \%$ in 2001 to $3.8 \%$ in 2004. A positive trend of the share of the agricultural sector in the segment of bank loans was noticed, from $4.1 \%$ to $6.7 \%$ (Haidutskyi, 2005).

Organizational changes in agricultural production were accompanied by trade liberalization in agricultural markets, reduction of government interference in the organization of supplies of materials and equipment and positive changes in price indexes for agricultural products compared to prices of resources. With the introduction of fixed agricultural tax the pressure on producers was reduced significantly. International economic activity of agricultural enterprises experienced institutional transformation through the introduction of export subsidies, import tariffs and quotas.

\section{c) Changes in foreign trade and formation of export potential}

Improvement of import and export operations becomes an essential element of agricultural policy of the country. At this stage pricing mechanism for the selling of Ukrainian products in foreign markets needs to be improved. Also, the necessary procurement is required to stimulate export of finished products with high added value, to establish a favorable investment climate and to increase budget support for agricultural producers. The Law of Ukraine "On stimulation of agricultural development for the period 2001 2004" was aimed at these tasks. The priority aim of agrarian policy was defined: the creation of a competitive, efficient and environmentally friendly agriculture.

During this period there was a departure from the strict vertical management of export potential to the liberalization of foreign trade. Measures to liberalize the exchange rate, to eliminate the majority of export and import restrictions were taken. The main economic operators also gained operational and economic independence. Institutional transformation in foreign economic activity took place through the introduction of export subsidies, import tariffs and quotas. Ukraine made reorientation of its trade relations. 
The range of cooperation extended from 43 to 57 countries. Although the CIS countries remained major trading partners, their share in total export of agricultural and food products decreased from $74 \%$ in 1996 to $46 \%$ in 2001.

Since the beginning of market reforms the share of other major regions of Ukraine's agriculture export and food industry products increased. The EU became the second powerful export market, whose share increased from $9 \%$ in 1996 to $18 \%$ in 2001. Ukraine got the status of supplier of crop products and raw materials in the EU market. This trend was typical for world export as well. The share of export in the total export of Ukraine was $9.5 \%$. The opposite situation was in the structure of import, where the largest share belonged to finished food products coming from the EU. Overall import of agricultural and food products compared to the previous period decreased slightly, especially concerning products of group III: animal or plant fats and oil. A positive balance of foreign trade proves the high level of market orientation (Appendix 1), it happened mainly due to an increase in wheat export. During the period of 2001-2002 Ukraine entered the group of leading grain exporters. It took the fifth place $(5.4 \%$ of world wheat export) after countries such as the US, Australia, Canada, Argentina. Ukraine entered the top ten countries that have the highest export investment attractiveness and significant competitive advantages for the main types of agricultural products (Luzan, 2002).

However, the export potential was not fully realized because the effective policy to stimulate export was not introduced. Competitive advantages of the agricultural sector in Ukraine increased mainly due to low base cost, but were lost because of the low level of state support. EU member countries gave this area more support at the expense of the European budget.

Thus, the main positive factor of foreign trade at this period was stabilization of exportimport operations. But the share of Ukraine's agro-food production in the world trade remained not significant. In 2003 it was $0.5 \%$ of the world export, while the share of France was $8 \%$, Germany - 6.3\%, US - 12\% (Haidutskyi et al., 2005). Ukraine lagged even from the average world rates in spite of high potential of the agricultural sector.

\section{d) The social consequences of transformations}

The priorities of this stage of reforms (the actual establishment of private land owner and formation of a self-contained entity of agricultural business) did not get proper support in rural areas. Unsystematic rural development, the pushing methods of implementing the reforms, the degradation of social infrastructure limited interest of rural people for entrepreneurship in agriculture. Among the rural workers of restructured collective agricultural enterprises only $6 \%$ wanted to create their own farm, $13 \%$ - to join their land shares to private households (Ostashko, 2000).

Some breakthrough in the attitude to farming, as well as the reforms in general, took place after the adoption of the President of Ukraine Decree "On urgent measures to accelerate reform of the agricultural sector" in 1999. This decree encouraged the process of registration of private land ownership by citizens.

Transfer of land ownership to the rural people contributed to the growth of their selfassessment. Sociological surveys show that $45 \%$ of rural people identified themselves as 
middle class of society (to compare, there were $12 \%$ less of such people in the cities). (Libanova, 2002). It was a kind of a social paradox, because the problem of the rural population poverty reached its critical point. The average family spent $64.5 \%$ of total expenditures on food and $65 \%$ of rural residents had average total costs below the subsistence level (Procopa, 2007).

In such circumstances, the idea of farming development was supported by about $64 \%$ of rural population (Goncharuk at al., 2000). As a result of the reforms 42.4 thousand of farms were created, which is the maximum number in the history of Ukraine (Garbar, 2014). However, even this peak in the development of farming did not lead to the formation of farmers' social and economic structure in rural areas. In 2004 the process of gradual transformation of farms into private households was launched. The reasons for this were the desire of farmers to avoid the tax burden and the inability to overcome bureaucratic barriers to business.

The deterioration of living standards and the lack of a clear vision of the perspective of the village development together with the direction of reforms led to a general negative social atmosphere. Thus, $12.7 \%$ of rural population assessed it as oppressed with persistent pessimism; $17.0 \%$ - as tense; $14.6 \%$ - as disintegrated (Ostashko, 2004).

In general, in the social sense, the main consequence of the reforms became irreversible deformation of the mentality of the rural population. After a long period of "collectivism" they felt individual landowners for the first time. Nevertheless, willingness of rural population to implement such public social and economic role in market conditions remained poor.

\subsection{The third stage (2004 - present time)}

The third stage beginning in 2004 and still continuing focused on reducing the impact of institutional barriers on the activities of agribusiness and intensification of agricultural production. Positive changes were: 1) growth of agricultural production; 2) improvement of the land rent institute; 3 ) formation of the work motivation institute; 4) stimulating value of the tax institutional innovations; 5) creating an attractive institutional investment climate in agriculture.

\section{a) Evolution of land relations}

This stage of land relations transformation presupposed physical allocation of land on the ground and creating conditions for free land use and regulations. The institutional basis for these changes was the introduction of the Land Cadastre (the Law of Ukraine "On State Land Cadastre", 2011). Every owner of the land unit had the right to freely leave the agricultural enterprise and freely manage their own land unit. The process of creating new agricultural enterprises, which started in the second stage of reform, was intensified.

During the land reform (1990-2012) more than 70\% of agricultural land was transferred to private ownership, including $81 \%$ of arable land for agricultural production. The average land share was approximately four hectares (Borodina, 2012). At the same time, citizens who received land shares subject to the designated purpose to carry out agricul- 
tural goods production did not cultivate that land personally. The main part of the land shares was leased to agricultural enterprises.

Since 2004 there have been processes of industrialization and corporatization of agriculture production based on the concentration of agricultural land and property in the agricultural sector of economy. The main feature of the stage was the consolidation of the large amounts of agricultural land. Horizontally and vertically integrated exportoriented structures were formed in the concentrated lands by attracting industrial, commercial and financial capital. According to their type they were close to latifundias and carried out the diversified agricultural production on hundreds and thousands of hectares of land (Andriychuk, 2015). A new type of agrarian formations of holding type used mostly medium-term lease agreements (5-7 years). This led to the fatigue of soil fertility and the deterioration of the quality of land.

The result of established relationships between the owners of capital/land and businessmen was inefficient use of land assets. Violations of scientifically reasoned standards of management and the introduction of monoculture were typical for the majority of agricultural holdings. There was a significant transformation in the structure of acreage by means of reducing forage crops seeding by 4-5 times, and simultaneously the amount of industrial crops seeding increased by almost 3 times, particularly sunflower almost to $19 \%$ (with the optimal value 10-12\%) (Appendix 1). A significant extension in the structure of acreage for energy-consuming crops (sunflower, corn, soybean, sugar beet etc.) encouraged their cultivation as a monoculture, which led to a decrease in soil fertility.

The issues regarding the formation of agricultural land market and providing institutional support for its operation gained considerable aggravation at the final stage of the transformation of land relations. The result of the transformation of land relations in Ukraine should be the formation of the agricultural land market.

The most important condition for the establishment of a proper land market was the adoption of private ownership of land, which gave the right to possess, to use and dispose it (Ciaian, 2012). Still the conditions for the practical realization of this right should be created. In its turn, this requires a favorable economic environment and the infrastructure of the land market. In Ukraine, the majority of the infrastructure elements of agricultural land market are still in the process of formation:

- $\quad$ inventory check and certification of land is being conducted,

- $\quad$ the state land cadaster is being updated, land exchanges are being created,

- the legal framework for the regulation of land market is being completed,

- the role of the state in regulating economic turnover of land is being discussed (Martin, 2013).

Taking this into consideration and due to the absence of a consensus in society, the moratorium on sales of agricultural land before the enactment of the Law "On circulation of agricultural land" (but not earlier than January 1, 2018) was continued.

\section{b) The efficiency of agricultural production}

Agriculture, with few exceptions, began to show positive dynamics. Thus, during 2005 2015 the production of gross agricultural output in all categories of enterprises in 
Ukraine increased by $33.3 \%$. The volume of production in crop industry rose by $47.1 \%$, and in livestock industry - by $9.1 \%$. The decline in production of gross agricultural output in 2007, 2010 and 2012 was mostly due to the crop sector as a consequence of the decrease of major crops harvest. Reduced production in 2014 and 2015 was connected with the occupation of the part of Ukrainian territory by the Russian Federation and with the warfighting, which made it impossible to carry out field works to prepare the fields, as well as to harvest crops in the area of anti-terrorist operation.

In the agribusiness system commercialization took place, and consequently, there was intensification of plant production (approximately $70 \%$ of total agricultural production). Enlarging the amount of land resources and a general increase in the number of agro holding structures contributed to the strengthening of this trend. In 2015 the total number of such companies was 132, and their land bank reached 5.6 million hectares of agricultural land. Apart from this, 32.3 thousand of farm use only 4.3 million hectares, while private households use 6.3 million hectares. In proportion to the share of land-use the share of agro holdings in the structure of production was $19.6 \%$, the share of farms $7.9 \%$, the share of private households $-44.9 \%$.

The increase of grain and leguminous crops yield in the period of institutional transformations indicates the deepening of specialization of holding companies. Their production focus is aimed at growing export-oriented, highly profitable and fast-payback crops. However, land consolidation carried out by agro holdings has tangible negative consequences: increased competition on the market of rent land relations, growth of the load on the soil; reducing the number of jobs due to technologisation of production processes.

As a result of the economic relations transformation and building a market mechanism livestock industry found itself in a deep economic crisis (Appendix 1). The consequences of the economic crisis in the livestock industry led to the concentration of livestock in private households: $66.3 \%$ of cattle; $49.2 \%$ of pigs; $85 \%$ of sheep and goats. Private households slightly increased the number of cattle using manual mode performance and minimum resource consumption for all technological operations. The process of economic recovery of livestock was visible only in the production of poultry meat, which provided the increase in the number of livestock. In particular, the growth of global demand for the products of this industry and access of Ukrainian producers on the world market contributed to this fact.

Despite the negative tendencies in the number of livestock, after 2005 the general profitability of agricultural production began to grow as presented in table 2 .

Table 2: Profitability Level of Agricultural Production in Agricultural Enterprises, \%

\begin{tabular}{l|c|c|c|c|c|c}
\hline & 1990 & 1995 & 2000 & 2005 & 2010 & 2015 \\
\hline Agricultural production - total & 42,6 & 13,6 & $-1,0$ & 6,8 & 21,1 & 45,9 \\
Crop production & 98,3 & 55,5 & 30,8 & 7,9 & 26,7 & 50,9 \\
Animal production & 22,2 & $-16,5$ & $-33,8$ & 5,0 & 7,8 & 22,6 \\
\hline
\end{tabular}

Source: UkrStat 
The profitability of agricultural production was provided by both internal (the principles compatible with the understanding of the logic of the laws of the market economy were established in management of the majority of farm enterprises) and external factors (the formation of agricultural market infrastructure, expansion of sales channels in foreign markets).

\section{c) Changes in foreign trade and formation of export potential}

Ukraine becomes actively involved in the international trade, increasing export and import of agro-food products from world countries. Among the general transformation processes that dominate in the world and influence the course of reforms in Ukraine's economy, the following are determined: globalization; intensification of interdependence; deepening of integration processes (Geec, 2002).

Implementation of the strategy of European integration and the involvement of Ukrainian agrarian economy into the process of globalization are restrained by domestic macroeconomic factors at this stage (Mogylnyi, 2005). In particular, a significant lag in terms of GDP per capita; incomplete privatization process and creation of all the attributes of social market economy; inconformity of state regulation with the European economic standards; political instability; monopoly dependence on the import of energy resources. Internationalization and external factors make the task more complicated. Among them increased international competition on trade and investment and credit markets, increasing demands of consumers to the technological level and product quality, new forms of protectionism, etc. (Gubskyi, 2000)

The legal and institutional basis for international trade relations was Ukraine's membership in the WTO in 2008. The cumulative impact of joining WTO was positive for the economic sectors of the country (Rossokha \& Sharapa, 2016). Formation of export capacity at this period developed by means of cooperation with international economic and financial organizations in foreign trade. The number of countries that became trade partners of Ukraine increased significantly. Ukraine carries out its foreign economic activity with more than 184 countries. The territory of foreign trade expanded, trade turnover with EU countries increased gradually.

Ukrainian scientists formed the point of view that taking into account the competitive advantages in the global market, agro-industry is one of the priority sectors of the economy (Dudar, 2009). This assertion is grounded and confirmed by relevant results.

Ukraine comes to the leading positions in the world regarding export, the country holds the first place in the export of sunflower oil (4.3 million tons), 3rd place in the export of corn (18 million tons), the fourth place in the export of barley (2.7 million tons), 6th in the export of wheat (11 million tons), seventh in the export of soybean ( 2 million tons), 8 th in the export of poultry meat (170 thousand tons) (Business Views, 2015). By increasing supply for all groups of agricultural and food products on the international market (Appendix 1), agrarian policy of Ukraine in the sphere of foreign trade relations encourages reduction of the world food prices and helps to avoid the problem of food security. In the geographical structure of export of agri-food products such countries as China, India, Egypt, Turkey, Spain, Iran, the Netherlands, Italy, Poland and Belarus dominated. At the same time, Ukraine is entering new markets in Asia and Africa. 
Unfortunately, the variety of goods, which is offered to these markets, is narrowed and it mainly consists of grain products. Reserve food resources of other branches of agriculture are used poorly, especially livestock. This requires a change in the structure of production and export in favour of the final product with a high added value, strong competitive advantages and high quality.

The most important step in the institutional transformations in the field of integration processes in Ukraine was the implementation of the Free Trade Area (FTA) between Ukraine and the EU (01.01.2016), which is part of the political economic association agreement between Ukraine and the EU (2014). The Agreement presupposes the establishment of a new format of export and import operations, aimed at trade liberalization and the promotion of agricultural export (Government Portal, 2016). The main goal, which was among the conditions of the Agreement, is to promote Ukrainian agri-food export. The goal is supposed to be accomplished by means of achieving competitive advantages of products with high level of recycling and significant added value. Introduction of new rules of production and export is a kind of "economic window to Europe" for Ukrainian producers of agricultural products. Among the innovations of the FTA Agreement, the implementation of which started during 2014-2015, the following ones should be highlighted: tariff liberalization (abolition of import taxes for the majority of Ukrainian and European agricultural products) and the administration of tariff quotas (establishing duty-free tariff quotas in trade with the EU).

Accordingly, we can notice a tendency of increasing the number of companies dealing with export of agri-food products. During the period from 2007/08 to 2014/15 marketing year, the number of companies that deal with exporting grain, crop oil and oilseeds increased by more than 3.5 times, namely from 374 to 1346 companies. Only in $2014 / 15$ marketing year the increase was $29.5 \%$ or 307 companies compared to the 2013/14 marketing year (Nibulon, 2016).

At the same time, the main participants of foreign trade are huge enterprises that produce agri-food products. They mostly have a holding structure of manufacturing and as a rule they export the most profitable types of crop production. Small and medium-sized enterprises (farms) are passive observers of the streams and geography of export. This, in its turn, shows the inadequacy of institutional (including legal) principles of formation of the ownership structure of the agricultural business, as well as inefficiency of correlation between the economic incentives and obligations.

An important principle of the development of the export potential is its monitoring based on the change of its volume, forming commodity pattern and geographical structure of export-oriented agro-food products. There is a constant growing dynamics of the foreign trade in Ukraine. The tendency of strengthening the export-oriented agricultural sector is ongoing. Throughout the periods of market transformations, especially at the current stage, positive foreign trade balance is maintained. The share of export of agricultural and food products in the total export in 2015 was $38.2 \%$, against $19.3 \%$ in 2010, 12.6\% in 2005 and 9.5\% in 2000 (Appendix 1).

Regarding the trade of agri-food products with the EU, Ukraine is more dependent on import of products of plant origin and finished food products. The terms of trade with the EU member countries impose the requirements to change the commodity structure of export in favour of products of complete product cycle. Calculations of commodity 
structure of export to the EU show that $63.9 \%$ of European export belongs to the final product, $21.7 \%$ to intermediate goods and only $14.4 \%$ for products that are the raw material. However, in the structure of export of Ukraine only $6.4 \%$ belongs to the final product, $44.1 \%$ to intermediate goods, $49,5 \%$ to the raw material (Lupenko, 2015).

A detailed analysis of the commodity structure of export for certain types of products confirms the dominance of raw component in the agro-food potential (Appendix 1). Slow export growth is observed in certain kinds of livestock production. Basically the increase of production volume is achieved owing to a small assortment of meat and dairy products: poultry meat, eggs, honey, and certain types of dairy products. The situation of low coverage of the European market with Ukrainian animal products can be explained by at least two reasons: first - a high level of competitiveness in the EU meat market and strict requirements for quality and safety of meat products; second - the positive tendency of diversification and reorientation of Ukrainian exporters of meat and by-products from the Russian market to markets in Asia and Africa, particularly to such countries as Egypt, Iraq, Jordan, the United Arab Emirates, Hong Kong, Vietnam, Kuwait and others. Overall, Asian markets consume about 30\% of Ukrainian export livestock products.

Despite the considerable potential of the agricultural sector, its dynamics is determined by the possibilities and conditions of selling a small number of agri-food products. The solution to this problem as the most important task of the national economy in terms of transformational changes in the foreign policy is the priority for Ukraine.

\section{d) The social consequences of transformations}

The start of the third stage of agrarian reforms in rural areas took place in accordance with the priorities of rural development stated in the Law of Ukraine "On the main activities of state agrarian policy for the period till 2015" and in "The Concept of the Comprehensive Program of Ukrainian Rural development for 2006-2010". However, declarativity of these regulations and lack of specific instruments and targets did not provide a comprehensive rural development. Under these conditions, social tension caused by unemployment and imbalance in the agricultural labor market is increasing. In 2005 the number of employees of agricultural enterprises decreased in comparison with 1990 by 4.7 times, and the number of employees in private households, on the contrary, increased by 4.1 times (Appendix 1). The asymmetry of supply and demand for rural labor negatively affected the welfare of rural population. This situation was the result of market-oriented changes in the behavior of agricultural producers and imperfect institutional environment for the formation of the labor market in agriculture. The components of this environment were:

- monopsonic type of agricultural labour market;

- land lost its priority in total income of rural people;

- $\quad$ wages failed their stimulating function (in the ranking of sources of income wages took 5th position (Ostashko, 2004), and its size was twice lower than the average for the economy);

- informal employment and hidden unemployment;

- members of the private households were considered to be employed;

- reluctance of farmers to carry out social insurance on a voluntary basis (Mohyl- 
nyi, 2013).

Low diversification of the rural economy and a high educational level of rural population (over $95 \%$ of the economically active population of the village had a secondary and higher education) led to the marginalization of a significant part of the rural population (Sikora, 2014). This situation pushes them below the poverty line, or makes them migrate from rural areas, where economic development level lags behind the cities considerably. In particular, $23 \%$ of rural households have average per capita income below the subsistence minimum. Poverty level in rural areas is 1.7 times higher than in urban areas. $39 \%$ of rural households are considered poor regarding the living conditions.

The problem of deterioration of social infrastructure of rural areas deepens. As a consequence of institutional changes of previous reform stages, enterprises transferred their social assets to local authorities and stopped taking care of them (Lerman, 2007). At the same time, local budgets do not have sufficient financial resources for the maintenance of social infrastructure, as most of them are subsidized. But the attitude of the rural population to social infrastructure remained traditional - only "consumption" without participation in the organization of their activities and funding.

Thus, it caused a need to change approaches to the formation of the policy of rural and local development, and to strengthen the role of rural communities. Institutional support for this model of rural development was included in the Law of Ukraine "On voluntary association of communities" (2015). In terms of decentralization of resources and authority rural communities become main stake holders of rural development policy. Community partnership becomes major aspect in the policy of rural development instead of rigid hierarchy and inefficient paternalism of the state. The importance of leadership asset of rural communities grows. There is an increase in powers of local selfgovernment (Borodina, 2015).

Thus, the social and economic development of rural areas will depend on the selforganization of rural population and implementation of top-down approach to rural development policy. This approach presupposes that the design of the policy, its content and instruments under specific local conditions will depend on the initiative and participation of local communities.

\section{Conclusions}

Institutional framework for the agricultural sector development was laid in a difficult period for the economy of Ukraine. Proper market mechanisms were not launched. The features of the administrative economy remained unchanged for quite a long time. Economic reforms did not become the evidence of economic growth and qualitative transformations in the agriculture. All this caused a number of controversial conclusions on the effectiveness of transformational changes in the agricultural sector over the period under study.

During the period of market reforms in Ukraine the structure of land fund was changed. Areas of arable land and the size of land in private use increased significantly. The efficiency of the agricultural land use was not achieved as a result of these changes. Also, the lack of institutional support slowed down the process of implementation and adherence to the scientifically based standards of management. Land relations at present 
stage take place in favor of agricultural holdings. To form a proper agricultural land market it is necessary to have an appropriate infrastructure and institutional support, which at this stage was still not fully formed. Permanent extension of the moratorium on the process of sale of agricultural land prevents the full use of financial instruments to attract investments through the credit mechanism.

During the period of agrarian reforms, Ukraine did not resume the production level of agricultural products which was reached at the beginning of the '90s. Only at the beginning of 2000s an increasing trend in gross output was noticed. Basically, these changes were achieved by the prevalence of grains and industrial crops (especially oil crops) in the structure of sowing areas. As a result of reforms in the agricultural sector a model with emphasis on raw materials nature was formed, which did not meet the internal needs of the population in high-quality and safe food. Also, direction at raw materials is not promising in the context of global trends in the development of agriculture.

Foreign trade of agro-food production during the period of institutional change tended to increase. A high level of openness of the national economy was achieved, Ukraine got membership in the WTO, and the number of importing countries was increased. Ukraine gets the leading position on the world and European markets for certain types of agricultural products.

However, the results of export and import activities in the agricultural sector were not the most important element of forming the strategic model of economic development. The main reason lies in the predominance of exporting plant and animal origin products and importing products of processing industries, i.e. finished food products. Insufficient development of knowledge-based industries, slow implementation of innovative and investment technologies in the production of agricultural products and finished food cannot provide a favorable investment climate in Ukraine. Export potential of the agricultural sector is not fully realized. Effective policy to stimulate and support export was not implemented. Competitive advantages are provided mainly by the low cost of agrofood products, and are lost because of the poor state support.

During the period 1990-2015 the role of agriculture in providing rural development process underwent radical changes. The industry remains strategic for the rural economy, but it is not able to fully meet social and economic needs of rural society. Low diversification of the rural economy and limited sources of non-agricultural employment shifted rural employment to the level of individual farm households. Employment in the individual farm households was informal and had limited development perspectives, it did not provide social protection, but it restrained the situation in rural areas from the "social fallout". Under the new economic conditions, radical changes concerning the overall life-support system in rural areas took place. Firstly, as a result of reforms the range of socially-oriented participants in rural development was narrowed - farm enterprises were exempt from the maintenance and development of social infrastructure objects. Secondly, the limited financial resources of local budgets did not allow to ensure the maintenance of infrastructure facilities at the appropriate level, and funding from the national budget was traditionally poor. Thirdly, rural population was not aware of the necessity to participate in the activities of infrastructure objects on the basis of self-organization and co-financing. The result was the disastrous gap in living conditions of the rural and urban population. This causes the outflow of young people to the 
cities, distortion of the age and gender structure of rural population, a gradual reduction in the total number of rural people, and deprecation of the rural way of life.

Perspectives for the development of the agricultural sector in Ukraine are laid in the restructuring of the existing institutional matrix. Improvement of institutional management and agribusiness development should be based on the implementation of European experience, particularly towards the harmonization of national objectives of agrarian policy with the basic rules of the CAP of the EU; trade liberalization through elimination of tariff and expansion of non-tariff control measures; approximation of legislative standards and the strengthening of the role of informal institutions in business processes, promoting social responsibility and so on.

Disclosure statement: No potential conflict of interest was reported by the authors.

\section{References}

ANDRIICHUK, V. (2015). Agribusiness challenges: finding answers. Economics of AIC. 5. p. 12-22.

ARONSSON T., LÖFGREN K.-G. (2007). Welfare Theory: History and Modern Results. / http://www.usbe.umu.se/digitalAssets/8/8218 ues726.pdf.

BORODINA, O. (2010). Social innovation in the system of rural development: conceptual approaches. Economy of Ukraine. 9. p. 68-77.

BORODINA, O. (2012). Ukrainian Model of Agricultural Development and its Socioeconomic Shift. Kyiv: Institute of Economics and Forecasting.

BORODINA, O. (ed.) (2015). Rural Development Policy Based on Communities in Ukraine: Scientific Report. Kyiv: Institute of Economics and Forecasting.

BURDEYNYUK, B. (2010). Land reform in Ukraine. What teach the achievements and failures. Land Management Journal. 1. p. 16-20.

BUSINESS VIEWS (2015). Agribusiness in Ukraine [Online] Available from: http://businessviews.com.ua/ru/agroreport2014/ [Accessed: 19th September 2016].

CALYUZHNA, N. (2014). Resource concept of potential interpretation in economic. The problems of economy. 2. p. 108-114.

CATYGROBOVA, O. (2013). Institutional changes as the basis to overcome the contradictions of innovative development. Investment: Practice and Experience. [Online] 13. p. 32-35 Available from: http://nbuv.gov.ua/UJRN/ipd_2013_13_9 [Accessed: 24th November 2016].

CIAIAN, P. at al. (2012). Institutional Factors Affecting Agricultural Land Markets. Brussels: Centre for European Policy Studies.

COASE, R. (1937). The nature of the firm. Economica. 4 (16). p. 386-405. DOI: 10.1111/j.1468-0335.1937.tb00002.x 
COMMONS, J. (1931). Institutional Economics. American Economic Review. 4(21). p. 648-657.

DIYESPEROV, V. (2010). Earth as the main natural resource and rural areas of the country. Economy AIC. 9. p. 102-109.

DOBRIAK, D. (2015). The current state of land reform and prospects of land relations development in Ukraine. Land Management Journal. 4. p. 2-4.

DUDAR, V. (2009). Analysis of competitive level of domestic agri-food production and perspectives of its increasing on world market. Innovative Economy. 4. p. 76-81.

EUROPEAN COMMISSION. Export Helpdesk. [Online] Available from: www.exporthelp.europa.eu [Accessed: 16th February 2016].

FEDOROV M.(2011) Land Reform and Development of Land Relations. Economy AIC. 7. p. 55-60.

GARBAR, V. (2014). Current status and trends of farms. Proceedings of Uman National University of Horticulture. 84. p. 214-221.

GEEC, V. (2002) The Market Transformation in Ukraine: Achievements, Challenges. Kyiv: Lybid.

GONCHARUK, O. at al. (2000). Social Problems of Collective Farms Reorganization. Kyiv: Institute of sociology.

GOVERNMENT PORTAL. The EU-Ukraine Association Agreement [Online] Available from: http://www.kmu.gov.ua/control/uk/publish/article?art id=248387631 [Accessed: 8th November 2016].

GUBSKYI, B., LUKYANENKO, D \& SIDENKO, V (2000). Internationalization of Ukrainian economy. Ukraine Economy. 9. p. 20.

HAIDUTSKYI, P. (2005). On main principles of reforming the state support system for agriculture and rural areas. Economics of AIC. 11. p. 43-48.

HAIDUTSKYI, P. et al. (2005). Agrarian Reform in Ukraine. Kyiv: Institute of Agrarian Economics.

LERMAN, Z. et al. (2007). Reforming Agricultural Sector in Ukraine. Rome: FAO.

LIBANOVA, E. at al. (2002). The Policy of the Middle Class. President of Ukraine Proclamation to the Verkhovna Rada of Ukraine. Kyiv.

LOPATINSKY, Y. (2006). Transformation of the Agricultural Sector: Institutional Foundations. Chernivtsi: Ruta.

LUKA, O. (2003). Ukraine on the agri-food products world market. Economics of AIC. 11. p. 116-121.

LUPENKO, Y. (2015). Present and Future of International Integration of the Ukrainian Agricultural Sector: the Tasks of Agroeconomics Science. Economy AIC. 6. p. 5-10.

LUZAN, Y. (2002). Reforming of Ukrainian agrarian sector: state and prospects. Economics of AIC. 4. p. 3-8. 
MALIK, M. and SHPYKULYAK, O. (2010). The institutionalization of the agricultural business: transformation and efficiency. Economics of AIC. 7. p. 132-139.

MAMCHUR, V. (2010). Institutional changes and agricultural policy in regional development. Economics of AIC. 4. p. 158-164.

MARTYN, A. (2013). The Land Market Regulation in Ukraine. Kyiv.

MITCHELL, W. (1927). Business Cycles, The Problem and Its Setting. New York: National Bureau of Economic Research. Inc.

MOGYLNYI, O. (2005). The Regulation of the Agrarian Sphere. Uzhgorod: IBA.

MOGYLNYI, O. (2013) Institutional features of rural unemployment in the context of the urgent tasks of state employment policy. Labor Economics and Employment Issues. 3. p. 5-10.

NIBULON. 2014/15 Marketing Year: the Results! [Online] Available from: http://www.nibulon.com/news/novini-kompanii/2014-15-marketingovii-rik-

pidsumki.html [Accessed: 6th February 2016].

NORTH, D. (1990). Institutions, Institutional Change and Economic Performance. Cambridge University Press

OSTASHKO, T. (2000). What peasants think about the agrarian reform: case study. Rural Reformer. 6(38). p. 4-6.

OSTASHKO, T. (2004). Market Transformation of Agrarian Sector. Kyiv: Fenics.

PADALKA, S. (2008). Ukrainian village's 1990-2000: tendencies of socio-economic changes. Ukrainian Historical Journal. 5. p. 169-184.

PORTER, M. (1985). Competitive Advantage. Free Press. 557 p.

PROCOPA, I. (2007). Rural areas in Ukraine: research and development regulation. Economics of AIC. 6. p. 50-59.

ROSSOKHA, V., SHARAPA O. (2016). Export potential of agricultural enterprises. Foreign Trade, Economics, Finance, Law. 4. p. 44-53.

SABLUK P. et al. (2005). Agricultural Complex in the System of Ukrainian Foreign Trade. Kyiv: Institute of Agrarian Economics.

SABLUK, P. (2001). Agricultural Economics and Policy in Ukraine: results of the past and the view to the future. Kyiv: Institute of Agrarian Economics.

SHEPOTKO, L. et al. (2000). Ukrainian Rural Sector on the Millennium Frontier - T. 1. Kyiv: Institute of Economics.

SIKORA, O. (2014). Saving and development of village human potential. Agrarian Economics. 7 (1-2). p. 79-86.

STATE STATISTICS SERVICE OF UKRAINE. (2004). Strategy for Economic and Social Development of Ukraine (2004-2015). Kyiv.

STATE STATISTICS SERVICE OF UKRAINE. (2016). Agriculture of Ukraine in 2015. [Online] Available from: http://www.ukrstat.gov.ua/. 
STATE STATISTICS SERVICE OF UKRAINE. (2016). Cooperation between Ukraine and EU countries in 2015. [Online] Available from: http://www.ukrstat.gov.ua/.

UKRAINE'S POPULATION. (2015). Statistics of Ukraine's population. [Online] Available from: http://database.ukrcensus.gov.ua/MULT/Dialog/statfile_c.asp.

USENKO, N. (2012). Rural youth: the place and role in the socio-economic relations of independent Ukraine (1991-2000). Journal of Agrarian History. 3. p. 150-157.

VEBLEN, T. (1899). The Theory of the Leisure Class: An Economic Study of Institutions. New York: The Modern Library

WILlIAMSON, O. (2001). Economic Institutions of Capitalism: Firms, marketing, contracting. Kyiv: Artek.

WORLD BANK (2004). Using Ukraine's Agricultural Potential: Stimulating Growth in Agriculture and Improve Life on Earth.

YAKUBA, K. (1999). Demographic Policy in Rural Areas of Ukraine. Kyiv: Institute of Agrarian Economics.

ZUBEC, M. at al. (1999). Social situation of the village: problems and prospects. Accounting in Agriculture. 6. p. 2-8. 
Volume 17, Issue 1, 2017

\section{Appendix 1: Indicators of Transformational Changes in Ukraine's Agriculture}

\begin{tabular}{|c|c|c|c|c|c|c|c|}
\hline Indicators & 1990 & 1995 & 2000 & 2005 & 2010 & 2015 & $\begin{array}{c}2015 \text { to } \\
1990 \\
+/-\end{array}$ \\
\hline \multicolumn{8}{|c|}{ Land use } \\
\hline Total lands million hectares & 60,3 & 60,3 & 60,3 & 60,3 & 60,3 & 60,3 & 0,0 \\
\hline $\begin{array}{l}\text { The sown area of agricul- } \\
\text { tural crops, hectares }\end{array}$ & 32,4 & 28,1 & 27,2 & 26,9 & 27,7 & 27,7 & $-4,7$ \\
\hline Level of plowed lands, $\%$ & 79,5 & 78,1 & 77,9 & 78,1 & 78,2 & 78,5 & $-1,0$ \\
\hline The structure of acreage, $\%$ & & & & & & & 0,0 \\
\hline a) cereals and legumes & 45,0 & 48,5 & 50,2 & 56,0 & 56,8 & 56,1 & 11,1 \\
\hline b) technical cultures & 11,6 & 13,2 & 15,4 & 27,1 & 26,9 & 29,0 & 17,4 \\
\hline including: sugar beets & 5,0 & 3,2 & 3,2 & 1,9 & 1,9 & 1,6 & $-3,4$ \\
\hline sunflower & 5,0 & 7,3 & 10,8 & 17,0 & 17,1 & 19,2 & 14,2 \\
\hline c) the forage crops & 37,0 & 30,1 & 26,0 & 9,6 & 9,0 & 8,2 & $-28,8$ \\
\hline \multicolumn{8}{|c|}{ Agricultural production } \\
\hline \multicolumn{8}{|l|}{$\begin{array}{l}\text { Production of main agricul- } \\
\text { tural crops, thousands tons: }\end{array}$} \\
\hline $\begin{array}{l}\text { Grain and leguminous } \\
\text { crops }\end{array}$ & 51009,0 & 33929,8 & 24459,0 & 38015,5 & 39270,9 & 60125,8 & 9116,8 \\
\hline Sugar beet & 44264,5 & 29650,4 & 13198,8 & 15467,8 & 13749,2 & 10330,8 & $-33933,7$ \\
\hline Sunflower & 2570,8 & 2859,9 & 3457,4 & 4706,1 & 6771,5 & 11181,1 & 8610,3 \\
\hline Potatoes & 16732,4 & 14729,4 & 19838,1 & 19462,4 & 18704,8 & 20839,3 & 4106,9 \\
\hline Vegetables & 6666,4 & 5879,8 & 5821,3 & 7295,0 & 8122,4 & 9214,0 & 2547,6 \\
\hline Fruits and berries & 2901,7 & 1897,4 & 1452,6 & 1689,9 & 1746,5 & 2152,8 & $-748,9$ \\
\hline $\begin{array}{l}\text { Number of livestock and } \\
\text { poultry, million heads: }\end{array}$ & & & & & & & 0,0 \\
\hline Cattle, total & 24,6 & 17,5 & 9,4 & 6514,1 & 4,5 & 3,7 & $-20,8$ \\
\hline including cows & 8,4 & 7,5 & 4,9 & 3635,1 & 2,6 & 2,2 & $-6,2$ \\
\hline Pigs & 19,4 & 13,1 & 7,6 & 7052,8 & 7,9 & 7,1 & $-12,3$ \\
\hline Sheep and goats & 8,4 & 4,1 & 1,8 & 1629,5 & 1,7 & 1,3 & $-7,1$ \\
\hline Poultry & 246,1 & 149,7 & 123,7 & $\begin{array}{c}161993 \\
5\end{array}$ & 203,8 & 203,9 & $-42,1$ \\
\hline \multicolumn{8}{|c|}{ Foreign trade of agricultural and provisions production } \\
\hline Export - total, MM USD & $\mathrm{x}$ & 14400,8 & 14572,5 & 34228,4 & 51405,2 & 38127,1 & $+23726,3$ \\
\hline $\begin{array}{l}\text { Exports of agricultural and } \\
\text { provisions production, total } \\
\text { (code I-IV) }\end{array}$ & $\mathrm{x}$ & 2983,4 & 1377,4 & 4307,0 & 9936,0 & 14563,1 & $+11579,7$ \\
\hline $\begin{array}{l}\text { I. Live animals and live- } \\
\text { stock products }\end{array}$ & $\mathrm{x}$ & 593,6 & 366,3 & 732,2 & 771,4 & 823,4 & $+229,8$ \\
\hline II. Plant products & $\mathrm{x}$ & 867,6 & 367,9 & 1695,9 & 3976,2 & 7971,5 & $+7103,9$ \\
\hline $\begin{array}{l}\text { III. Animal or plant fats } \\
\text { and oils }\end{array}$ & $\mathrm{x}$ & 185,6 & 240,1 & 587,2 & 2617,3 & 3299,8 & $+3114,2$ \\
\hline IV. Finished food products & $\mathrm{x}$ & 1336,6 & 403,1 & 1291,7 & 2571,1 & 2468,4 & $+1131,8$ \\
\hline
\end{tabular}




\begin{tabular}{|c|c|c|c|c|c|c|c|}
\hline $\begin{array}{l}\text { Share of export of agricul- } \\
\text { tural and provisions pro- } \\
\text { duction in total export , } \%\end{array}$ & $\mathrm{x}$ & 20,7 & 9,5 & 12,6 & 19,3 & 38,2 & $\mathrm{x}$ \\
\hline Import - total, MM USD & $\mathrm{x}$ & 17603,4 & 13956,0 & 36136,3 & 60742,2 & 37516,4 & $+19913,0$ \\
\hline $\begin{array}{l}\text { Imports of agricultural and } \\
\text { provisions production, total } \\
\text { (code I-IV) }\end{array}$ & $\mathrm{x}$ & 1448,1 & 908,2 & 2684,1 & 5763,6 & 3484,4 & $+2036,3$ \\
\hline $\begin{array}{l}\text { I. Live animals and live- } \\
\text { stock products }\end{array}$ & $\mathrm{x}$ & 316,1 & 104,5 & 499,6 & 1242,0 & 548,2 & $+232,1$ \\
\hline II. Plant products & $\mathrm{x}$ & 246,8 & 302,8 & 525,5 & 1563,9 & 1146,2 & $+899,4$ \\
\hline $\begin{array}{l}\text { III. Animal or plantfats and } \\
\text { oils }\end{array}$ & $\mathrm{x}$ & 36,9 & 61,2 & 204,1 & 451,6 & 182,3 & $+145,4$ \\
\hline IV. Finished food products & $\mathrm{x}$ & 848,3 & 439,7 & 1454,9 & 2506,1 & 1607,7 & $+759,4$ \\
\hline $\begin{array}{l}\text { Share of import of agricul- } \\
\text { tural and provisions pro- } \\
\text { duction in total im- } \\
\text { port } \%, \%\end{array}$ & $\mathrm{x}$ & 8,2 & 6,5 & 7,4 & 9,5 & 9,3 & $\mathrm{x}$ \\
\hline $\begin{array}{l}\text { Balance of foreign trade } \\
\text { (export - import), MM, } \\
\text { USD }\end{array}$ & $\mathrm{x}$ & $-3202,6$ & $+616,5$ & $-1907,9$ & $-9337,0$ & $+610,7$ & $\mathrm{x}$ \\
\hline $\begin{array}{l}\text { Balance of foreign trade of } \\
\text { agricultural and provisions } \\
\text { production (export - im- } \\
\text { port), MM USD }\end{array}$ & $\mathrm{x}$ & $+1535,3$ & $+469,2$ & $+1622,9$ & $+4172,4$ & $+11078,7$ & $\mathrm{x}$ \\
\hline \multicolumn{8}{|c|}{ Social consequences } \\
\hline $\begin{array}{l}\text { Number of agricultural } \\
\text { employees, thousand peo- } \\
\text { ple }\end{array}$ & 4881 & 3801 & 2475 & 1038 & 595 & 417 & $-4464,0$ \\
\hline $\begin{array}{l}\text { Number of employed in } \\
\text { private farms, thousand } \\
\text { people }\end{array}$ & 681 & $\mathrm{n} / \mathrm{a}$ & 2233 & 2785 & 2451 & 2372 & 1691,0 \\
\hline $\begin{array}{l}\text { Ratio of wages in agricul- } \\
\text { ture to the average for the } \\
\text { economy, } \%\end{array}$ & 90,2 & 50,7 & 48,3 & 51,5 & 63,9 & 63,3 & $-26,9$ \\
\hline $\begin{array}{l}\text { The share of revenues from } \\
\text { subsidiary farming house- } \\
\text { holds in total resources, } \%\end{array}$ & 10,2 & 31,9 & 48,3 & 28,2 & 23,8 & 22,0 & 11,8 \\
\hline $\begin{array}{l}\text { Quantity of rural popula- } \\
\text { tion, million people }\end{array}$ & 16,9 & 16,6 & 16,1 & 15,3 & 14,4 & 13,3 & $-3,7$ \\
\hline $\begin{array}{l}\text { Quantity of villages, thou- } \\
\text { sand }\end{array}$ & 28,8 & 28,86 & 28,74 & 28,58 & 28,47 & 28,39 & $-0,4$ \\
\hline $\begin{array}{l}\text { Quantity of rural popula- } \\
\text { tion per } 1 \text { village, people }\end{array}$ & 589 & 576 & 560 & 534 & 507 & 467 & $-122,0$ \\
\hline
\end{tabular}

